\title{
Reconciling internalization theory and the eclectic paradigm
}

\section{Article}

Published Version

Rugman, A. M. (2010) Reconciling internalization theory and the eclectic paradigm. Multinational Business Review, 18 (2). pp. 1-12. ISSN 1525-383X doi:

https://doi.org/10.1108/1525383X201000007 Available at https://centaur.reading.ac.uk/6112/

It is advisable to refer to the publisher's version if you intend to cite from the work. See Guidance on citing.

To link to this article DOI: http://dx.doi.org/10.1108/1525383X201000007

Publisher: Boeing Institute of International Business at Saint Louis University

All outputs in CentAUR are protected by Intellectual Property Rights law, including copyright law. Copyright and IPR is retained by the creators or other copyright holders. Terms and conditions for use of this material are defined in the End User Agreement.

\section{www.reading.ac.uk/centaur}

\section{CentAUR}

Central Archive at the University of Reading

Reading's research outputs online 


\title{
Reconciling Internalization Theory and the Eclectic Paradigm
}

Alan M. Rugman

\begin{abstract}
The eclectic paradigm of Dunning (1980) (with its OLI and four motives for FDI framework) can be reconciled with the firm and country matrix of Rugman (1981). However, the fit is not perfect. The main reason for misalignment is that Dunning is focused upon outward FDI into host economies, whereas Rugman's matrix is for firm-level strategy covering MNE activity in both home and host countries.
\end{abstract}

Keywords: internalization theory, Dunning's eclectic paradigm, firm-specific advantages, country specific advantages, multinational enterprises.

\section{INTRODUCTION}

The field of international business has largely been developed over the last forty years through the insight and leadership of John Dunning. At the University of Reading he built upon the theory of internalization developed by his colleagues, Peter Buckley and Mark Casson (Buckley and Casson 1976), to develop what has become known as the eclectic paradigm (Dunning 1980, 1981, 1988). Together, internalization theory and the eclectic paradigm provide the cornerstones for the current theory of the multinational enterprise (MNE) (Verbeke 2009). They also provide the intellectual foundations for the rigorous theoretical and empirical analysis which characterizes research on MNEs at what has become known as the "Reading School" of international business (Rugman 2009).

Alan M. Rugman is a distinguished visiting Professor at Saint Louis University and Editor-in-Chief of Multinational Business Review. He is also a Professor of International Business at Henley Business School, University Of Reading, U.K.

Email: a.rugman@henley.reading.ac.uk

Acknowledgements: I am grateful to John H. Dunning for suggesting this paper, and to Alain Verbeke, Mark Casson, Lorraine Eden, Rajneesh Narula, and other colleagues at the April 2009 Reading Conference for very helpful comments. 


\section{DunNing's ECLECTIC PARADIGM}

The eclectic paradigm has been developed by John Dunning in a series of publications (Dunning 1980, 1981, 1988, 1992). There are three factors that determine the international activities of multinational enterprises (MNEs). These are ownership (O) advantages, location (L) advantages, and internalization (I) advantages. Thus, the Dunning eclectic paradigm is also known as the OLI paradigm. The OLI paradigm explains outward foreign direct investment (FDI). It suggests that MNEs develop competitive $\mathrm{O}$ advantages at home and then transfer these abroad to specific countries (depending on L advantages) through FDI, which allows the MNE to internalize the $\mathrm{O}$ advantages. In contrast to the eclectic paradigm, internalization theory is mainly used to explain the choice of entry mode. For example, I advantages overcome the externality of knowledge as a public good, such that FDI is preferred to licensing, joint ventures, or alliances. (In all of the last three modalities, there is a risk of dissipation of the firm's knowledge advantage.) Using Dunning's own reasoning, it is apparent that there is a close linkage between $\mathrm{O}$ and I advantages in that a knowledge-type $\mathrm{O}$ advantage needs to be internalized. As will be shown below, this process is best analyzed by transaction cost analysis at the firm level. In contrast, $\mathrm{L}$ advantages can be fully explained by country-level analysis.

One of the problems with Dunning's eclectic paradigm is that it is too eclectic. Indeed, in many ways, each of the three motives for FDI is overdetermined. This is especially true for $\mathrm{O}$ advantages. According to Dunning, these include not only the firm's intangible assets, such as knowledge, brands, organizational structure, and management skills, but also natural factor endowments; manpower; capital; the cultural, legal and institutional environment; and industry market structure. Obviously the latter set of $\mathrm{O}$ advantages is easier to analyze as country factors. However, Dunning argues that such country factors can somehow be turned into O advantages. Going one step further, Dunning (1993) argued that O advantages could explain the ability of MNEs to form alliances. MNEs do this by taking advantage of common governance structures across borders, such that relational assets are created which allow firms to access resources controlled by partners. This is a form of business networks or alliance capitalism, driven by a very broad interpretation of $\mathrm{O}$ advantages. (See the Appendix for a more detailed discussion of $\mathrm{O}$ advantages.)

In a similar manner, Dunning has a very broad definition of location (L) advantages. Here it is host country L advantages that matter, including market size, natural resources, aspects of the infrastructure, the education 
system, governance structures, and other aspects of political and government activity. Given that firms can lobby governments to obtain sheltertype $\mathrm{O}$ advantages, the distinction between $\mathrm{L}$ and $\mathrm{O}$ advantages is difficult to make. For example, when an MNE is given access to natural resources (ownership of an oil well, a forest, or a mine), a host country L advantage is transformed into an $\mathrm{O}$ advantage.

Finally, I advantages are clearly strongly linked to $\mathrm{O}$ advantages. Indeed, without the institutional form of the MNE it is difficult to see how $\mathrm{O}$ advantages could exist on their own without being owned (internalized) by the firm. In their essence, intangible knowledge assets are an example of the firm replacing the market (Williamson 1975; Buckley and Casson 1976; Rugman 1981; Hennart 1982). Dunning seems to argue that the I advantage only relates to transaction costs, such that an $\mathrm{O}$ advantage is needed to explain organizational, financial, and institutional advantages. This distinction between transactional ownership advantages and asset ownership advantages was introduced by Dunning and Rugman (1985). However, this paper also argued that Hymer-type advantages (1960) needed to be internalized by the firm in order to explain FDI activity.

\section{Reconciling The eClectic PARADigm With INTERNALIZATION THEORY}

Internalization theory, as developed by Buckley and Casson (1976), Rugman (1981), and Hennart (1982), is a firm-level theory explaining why the MNE will exert proprietary control (ownership) over an intangible, knowledge-based, firm-specific advantage (FSA). In internalization theory, all FSAs are efficiency-based. The knowledge advantage arises from a transaction cost economics explanation, whereby the public good nature of knowledge (an externality) is remedied through the hierarchy of a firm overcoming this situation of market failure. The other types of FSAs, such as brand advantage, skills in management, and organizational capabilities, are also efficiency-based and are compatible with the resourcebased view (RBV) and the value creation aspects of Penrose (Rugman and Verbeke 2002). In short, internalization theory applies transaction cost economics and the RBV to explain the efficiency aspects of MNEs.

In contrast, the eclectic paradigm adds Hymer-type advantages (1960) to the efficiency-based FSAs of internalization theory. As demonstrated in Dunning and Rugman (1985), some Hymer advantages serve to close markets and provide potential rents to the MNE. These are the asset-based $\mathrm{O}$ advantages of the eclectic paradigm. They need to be distinguished from the transaction-based $\mathrm{O}$ advantages of internalization theory. The distinc- 
tion between asset-based $\mathrm{O}$ advantages and transaction-based $\mathrm{O}$ advantages, introduced by Dunning in 1981, is potentially misleading to scholars in international business. Dunning seems to regard internalization theory as only dealing with the transaction as the unit of analysis (possibly because it is based upon transaction cost economics), whereas Buckley and Casson (1976), Rugman (1981), Hennart (1982), and subsequent writings have all demonstrated that internalization theory takes the firm as the unit of analysis. This is why FSAs were defined in Rugman (1981) as the relevant advantages. The FSAs are obviously at firm level and not at transaction level.

Indeed, contrary to the firm-level analysis at the core of internalization theory, the eclectic paradigm is more of an industry-level analysis. The mingling of $\mathrm{O}, \mathrm{L}$, and I advantages serves to explain outward FDI and, although this has firm-level implications, has been mainly tested at industry level (Dunning 1992). Furthermore, the extension of the eclectic theory to explain economic development in the investment development path offers industry-level analysis to explain the expansion patterns of industries and countries (Dunning and Narula 1996). The essence of the eclectic theory is that the $\mathrm{O}, \mathrm{L}$, and I advantages interact to produce a rich (almost co-evolutionary) explanation of the patterns of overseas FDI at industry level. In contrast, internalization theory is a firm-level explanation of FDI, which is able to focus upon the strategic decision-making of the MNE and is able to demonstrate the heterogeneity of firm-level behavior within any industry.

Internalization theory also differs from the eclectic paradigm in its treatment of the mode of entry. With internalization theory, the MNE can choose to expand abroad either through FDI (retaining knowledge-based FSAs), or it can choose another form of entry, such as licensing, joint ventures, or alliances (all of which lead to potential dissipation of the knowledgebased FSA of the MNE). The relative costs and benefits of the choice of entry mode will vary over time, potentially leading the MNE to sequence foreign entry through FSA control mechanisms, such as exporting and FDI, to be followed later by more risky modes, such as alliances, joint ventures, and licensing. For models of the dynamics of the choice of entry mode, see chapter 3 in Rugman (1981) and Buckley and Casson (1981). In short, internalization theory explores the hazards of doing business across different entry modes, where the FSAs of the MNE need to be offset against both dissipation risks and the liability of foreignness in entering into risky foreign markets (Rugman and Verbeke 2003). 
The treatment of location advantages and the choice of entry mode in the eclectic paradigm is much broader (and theoretically less precise) than in internalization theory. The eclectic paradigm examines the interactions between $\mathrm{O}, \mathrm{L}$, and I at industry level. In this way, it is much closer to conventional international economics than is the RBV approach of internalization theory. For example, in the eclectic theory aspects of the L variable (such as ownership of natural resources or government controlled businesses) are transformed into $\mathrm{O}$ advantages. Similarly, the asset-seeking motive for FDI advanced by Dunning confuses the desire of a home country firm in seeking knowledge with the locational availability of such knowledge in a host country. Absent from the asset-seeking motive for FDI is any rationale as to why knowledge would be sold to the foreign firm. This type of confusion comes from an approach which ignores the critical role of the firm in generating and controlling knowledge. Using the logic of internalization theory, it would be extremely rare for asset-seeking FDI to exist. No firm in the knowledge-intensive country would have an advantage in dissipating its knowledge-based FSA to a potential rival asset-seeking firm.

To summarize, the broad nature of the eclectic paradigm, with its focus on industry-level data and the comingling of $\mathrm{O}, \mathrm{L}$, and I advantages, leads to a more descriptive, indeed holistic, explanation of the motives of outward FDI. In contrast, internalization theory has a narrower and more parsimonious focus upon the intangible knowledge advantages of MNEs. It is therefore more analytical and predictive than the eclectic paradigm. As a result, Rugman (1981) argued that the two key determinants of FDI are country-based factors, called country specific advantages (CSAs), and firm-level factors, called firm specific advantages (FSAs). We now turn to a section which relates the eclectic paradigm to this FSA/CSA framework.

\section{THE ECLECTIC PARADIGM AND THE FSA/CSA FRAMEWORK}

In a popularization of internalization theory, Rugman (1981) outlined the firm and country factors relevant for analysis of MNE activity. It built upon internalization theory to construct a matrix which brings together firm specific advantages (FSAs) and home country specific advantages (CSAs). The axes of this matrix are discussed in Rugman (1981), but the matrix itself was not published until work in the mid 1980s. (For a summary, see Rugman and Verbeke 1990, 2008). It will be noted that the FSA/CSA matrix has two axes, whereas there are three variables in Dunning's eclectic paradigm. Obviously these three variables cannot be reconciled with the FSA/ CSA matrix in a one-to-one mapping, although the location variable in Dunning is an exact match with the CSA axis in the Rugman matrix. Thus 
the conceptual difficulty lies in dealing with Dunning's $\mathrm{O}$ and I. For some time Rugman has suggested that these be combined into the FSA axis of his matrix (Rugman and Collinson 2006; Rugman 2009) (For an early statement to this effect, see Rugman and Verbeke (1992), and for a more recent interpretation see Rugman and Verbeke (2008).) What is the rationale for incorporating Dunning's OLI into the FSA/CSA matrix?

First, Dunning defines location variables as those dealing with host country factors, such as the labor force, natural resources, market size, and other environmental factors, including culture. It is important to note that he also includes aspects of host country government behavior in the L variable. These $L$ variables are precisely the country factors in the CSA axis of the Rugman FSA/CSA matrix. However, Rugman first develops the FSA/ CSA matrix for MNEs in the home country (of course, the framework can also be applied to host countries simply by drawing a second matrix with host CSAs, or by relabeling the original matrix in this way). In situations where Rugman discusses home country CSAs, there is some dissidence with Dunning's L variable (which he explicitly states is for host countries). Overall, there is no substantive difference between Rugman and Dunning regarding the reconciliation of the $\mathrm{L}$ variable with the CSA axis.

Second, Rugman has argued that $O$ and I can be usefully combined and incorporated on the FSA axis of his matrix. The primary reason is that ownership advantages are firm specific, as is the internalization process. In other words, the outward FDI of interest to Dunning is undertaken by MNEs, who are the agents to simultaneously internalize and exert proprietary control (ownership) over the use of scarce, firm-specific, knowledgebased advantages. Using a strict Coase-Williamson view of internalization (whereby knowledge is a public good which needs to be owned and internalized by a firm in light of the public goods externality of knowledge creation), it is apparent that both $\mathrm{O}$ and I are central to explaining the knowledge FSA of an MNE. Also, when Hymer (1960) monopoly-type "advantages" are being considered (such as scale, differentiation, resource access, distribution channels, access to financial capital, etc.), it is also appropriate to consider these as FSAs in which there are combinations of $\mathrm{O}$ and $\mathrm{I}$ advantages. Thus, the firm (MNE) becomes the institutional mechanism for linking $\mathrm{O}$ and $\mathrm{I}$ on the FSA axis of the matrix.

\section{THE FSA/CSA MATRIX AND DUNNING'S FOUR MOTIVES FOR FDI}

The conclusion is that the OLI paradigm neatly transforms into the FSA/ CSA matrix. Further evidence of this can be provided when we consider the four motives for FDI developed by Dunning (e.g., Dunning 1992; 
Dunning and Lundan 2009). Dunning's four motives for FDI are as follows: natural resource-seeking; market-seeking; efficiency-seeking; and strategic asset-seeking. These can be incorporated into the FSA/CSA matrix, as shown in Figure 1.

Figure 1. The Eclectic Paradigm's Motives for FDI in the FSA/CSA Matrix

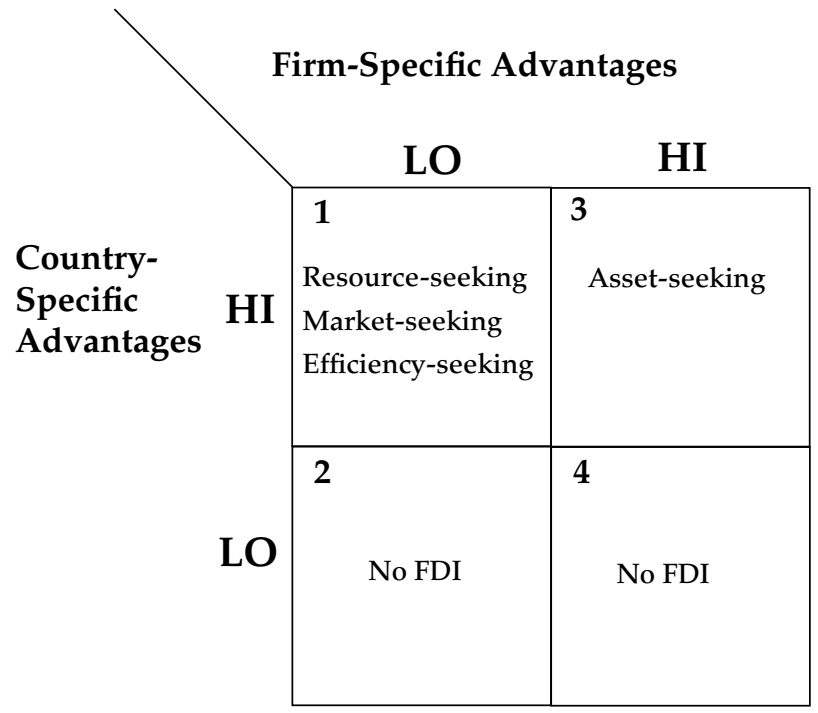

In Figure 1, cell 1 is a situation where host country CSAs matter and the FSAs of home country firms do not when determining outward FDI. In Dunning's terms, cell 1 will contain resource-seeking FDI. The home country MNEs want access to host country natural resources, cheap labor, favorable host country government policies, etc. Cell 1 is also where market-seeking FDI can be identified. Here the home country MNE needs access to the size and consumer base in the host country. Also important for market-seeking FDI is the extent and quality of host country infrastructure, supplier networks, special clusters, and supportive host government policies. In short, both resource-seeking FDI and market-seeking FDI are largely explained by the strong CSAs in cell 1.

In cell 2, there is a lack of both FSAs and CSAs, which suggests that no FDI will be taking place in the host country.

In cell 3, we have asset-seeking FDI. Here, home country MNEs (today mainly from emerging economies) go to a host country in the hope of acquiring knowledge-related assets. Of course, such asset-seeking FDI is 
only half the story. While emerging economy MNEs may want to acquire knowledge, there is no reason to believe that firms in the host countries will want to sell it to them. Therefore, asset-seeking FDI is a weak form of FDI; it is only a partial explanation, since the completion of this strategy lies outside of the control of the home country firm. Frankly, the attention paid to asset-seeking FDI over the last twenty years is probably unjustified; it is very doubtful that much of it actually takes place. Even if home country firms attempt non-equity types of FDI, such as joint ventures or collaborative alliances, it is difficult to believe that knowledge is actually being transferred to them in a dynamic sense. For example, Lenovo's acquisition of the IBM PC division, while potentially an asset-seeking FDI, may well not lead to future knowledge generation by Lenovo. Similarly, takeovers of creative service firms are unlikely to lead to ongoing knowledge generation (Rugman and Doh 2008).

Cell 1 is also relevant for efficiency-seeking FDI. It is not in cell 3, which would require that the home country MNE have very strong FSAs which are related to host country CSAs. Instead, these are cost efficiencies, such as saving on labor costs in a foreign country, which clearly fall under a type of FSA based upon the CSA in cell 1. Indeed, in Dunning's work on efficiency-seeking FDI, he explicitly embeds this motive as being dependent upon host country advantages, such as factor endowments and government policy. All such country effects are in cell 1.

Cell 4 cannot include any of Dunning's four motives for FDI. The reason is that Dunning has developed the OLI paradigm, including the four motives for FDI, within the context of outward FDI directed towards host country locations. Therefore, in terms of Figure 1, high CSAs are required for each of Dunning's four motives for FDI.

\section{Conclusions}

The traditional FSA/CSA matrix in Rugman (1981) explains an MNE's outward FDI based upon home country CSAs and FSAs. Thus it is a home country, outward FDI framework. In contrast, Dunning's eclectic paradigm uses the OLI variables to determine outward FDI on the basis of opportunities in host countries, i.e., host country CSAs matter. Further, all of Dunning's OLI variables are analyzed from the viewpoint of the host country; thereby, his four motives for FDI (natural resource-seeking, market-seeking, efficiency-seeking, and strategic asset-seeking) all appear as reasons for FDI in a host economy. 


\section{REFERENCES}

Buckley, P.J., and M.C. Casson. 1976. The future of multinational enterprises. London: Macmillan.

Buckley, P.J., and M.C. Casson. 1981. The optimal timing of a foreign direct investment. The Economic Journal 91: 75-87.

Cantwell, J. 2001. Innovation and information technology in the MNE. In The Oxford Handbook of International Business, ed. A.M. Rugman, 431456. Oxford: Oxford University Press.

Caves, R.E. 1982. Multinational enterprise and economic analysis. Cambridge, and New York: Cambridge University Press.

Caves, R.E. 1996. Multinational enterprise and economic analysis. $2^{\text {nd }}$ ed. Cambridge and New York: Cambridge University Press.

Dunning, J.H. 1980. Toward an eclectic theory of international production: some empirical tests. Journal of International Business Studies 11(1) (Spring/Summer): 9-31.

Dunning, J.H. 1981. International production and the multinational enterprise. London: Allen and Unwin.

Dunning, J.H. 1988. Explaining international production. London: Unwin Hyman.

Dunning, J.H. 1992. Multinational enterprises and the global economy. Wokingham, UK and Reading, MA: Addison-Wesley Publishing Company.

Dunning, J.H. 1993. The globalization of business. London and New York: Routledge.

Dunning, J.H. 1997. Alliance capitalism and global business. London: Routledge.

Dunning, J.H., and S. Lundan. 2009. Multinational enterprises and the global economy. $2^{\text {nd }}$ ed. Cheltenham, UK: Edward Elgar.

Dunning, J.H., M. Fujita, and N. Yakova. 2007. Some macro-data on the regionalisation/globalisation debate: a comment on the Rugman/ Verbeke analysis. Journal of International Business Studies 38(1): 177199.

Dunning, J.H., and R. Narula. 1996. The investment development path revisited. In Foreign direct investment and governments, ed. J.H. Dunning and R. Narula, 1--41. London and New York: Routledge.

Dunning, J.H., and A.M. Rugman.1985. The influence of Hymer's dissertation on the theory of foreign direct investment. American Economic Review, Papers and Proceedings 75(2): 228-232. 
Hennart, J-F. 1982. A theory of multinational enterprise. Ann Arbor, MI: University of Michigan Press.

Hymer, S.H. 1960. The international operations of national firms: A study of direct foreign investment. PhD thesis, Massachusetts Institute of Technology.

Rugman, A.M. 1981. Inside the multinationals. London: Croom Helm.

Rugman, A.M. 2009. Rugman reviews international business. New York: Palgrave Macmillan.

Rugman, A.M., and S. Collinson. 2006. International business. $4^{\text {th }}$ ed. London: FT Prentice Hall.

Rugman, A.M., and J.P. Doh. 2008. Multinationals and development. New Haven, CT \& London: Yale University Press.

Rugman, A.M., and A.Verbeke. 1990. Global corporate strategy and trade policy. London and New York: Routledge.

Rugman, A.M., and A. Verbeke. 1992. Multinational enterprise and national economic policy. In Multinational enterprises in the world economy: Essays in honour of John Dunning, ed. P.J. Buckley and M. Casson, 194-211. Aldershot, UK: Edward Elgar.

Rugman, A.M., and A. Verbeke. 2002. Edith Penrose's contribution to the resource-based view of strategic management. European Management Journal 23(8): 769-780.

Rugman, A.M., and A.Verbeke. 2003. Extending the theory of the multinational enterprise: internalization and strategic management perspectives. Journal of International Business Studies 34(2): 125-137.

Rugman, A.M., and A. Verbeke. 2004. A perspective on regional and global strategies of multinational enterprises. Journal of International Business Studies 35(1): 3-18.

Rugman, A.M., and A.Verbeke. 2007. Liabilities of foreignness and the use of firm-level versus country-level data: a response to Dunning et al. (2007). Journal of International Business Studies 38(1): 200-205.

Rugman, A.M., and A.Verbeke. 2008. Internalization theory and its impact on the field of international business. In International business scholarship: AIB fellows on the first 50 years, ed. J.J. Boddewyn, 155-174. Bingley, UK: Emerald.

Verbeke, A. 2009. International business strategy. Cambridge: Cambridge University Press.

Williamson, O.E. 1975. Markets and hierarchies: Analysis and antitrust implications; A study of the economics of internal organizations. New York: Free Press.nal 26: 809-825. 


\section{APPENDIX: THE END OF OWNERSHIP ADVANTAGES}

The tension between internalization theory and the eclectic paradigm is largely confined to differing views about ownership advantages. In both frameworks, the internalization variable is used to explain the modality of foreign entry. There are situations in which FDI by wholly owned subsidiaries (I) is preferable to licensing or joint ventures. This is the situation when the MNE has an intangible, knowledge-based FSA and needs to prevent its dissipation in foreign markets through the use of an internal market (Rugman 1981). Dunning (1993) basically agrees with this premise. Empirical research on knowledge generation and innovation within the MNE also broadly supports this thinking (Caves 1982, 1996; Cantwell 2001; Dunning 1997).

The location variable exhibits a lower degree of congruence in the internalization and eclectic frameworks. Internalization theory treats location as country factors, or CSAs. These are exogenous. Dunning's view of location is basically that of a country level economist's theory of comparative advantage. He examines home and host country CSAs. However, these may not necessarily be exogenous to the firm, as in internalization theory. The area of agreement across the two frameworks is that CSAs such as factor endowments (labor, natural resources, government policy, etc.) can be assessed. Therefore, the $\mathrm{L}$ variable of the eclectic paradigm relates relatively strongly to the home country CSA axis of internalization theory. Indeed, Dunning agrees with Rugman that the CSA axis can be redrawn to represent host country CSAs, or to represent net differentials between home and host country CSAs.

The key difference between internalization theory and the eclectic paradigm occurs due to the use of ownership advantages by Dunning (1981). Dunning defines ownership advantages to include not only firm-level capabilities but, also, the resources and capabilities of the home country. Dunning explicitly states that ownership advantages include intangible, firm-specific assets, such as knowledge, organizational and managerial skills, brand names, etc. But, he then states that $\mathrm{O}$ advantages also include home country institutional factors, such as the cultural and legal environment, and tangible assets, such as labor and natural resources. Obviously, such institutional and tangible assets should not be defined as $\mathrm{O}$ advantages but as L advantages.

One conclusion to be drawn from the mistreatment of $\mathrm{O}$ advantages by Dunning $(1981,1993)$ is that the eclectic paradigm is inconsistent with the 
resource-based view (RBV) of the firm. The RBV requires a focus upon firm-level capabilities, i.e., the FSAs of internalization theory. The RBV would not regard generally available country-level attributes such as labor, natural resources, and the institutional environment as firm-specific capabilities.

It is not surprising that the eclectic paradigm includes too many items as $\mathrm{O}$ advantages. Dunning does not have a firm-level theory of the international firm. Instead, he is more interested in explaining patterns of FDI, which is a country-level approach rather than a firm-level approach. Indeed, Dunning et al. (2007) recently offered country-level data on FDI patterns to demonstrate and complement the original firm-level empirical evidence on regionalization by Rugman and Verbeke (2004, 2007).

This provides a clue as to the ambiguities in the eclectic paradigm. The empirical research in the international business field demonstrates a high degree of correlation between country-level outward FDI data and firmlevel foreign sales data. But, that is not surprising, since it is MNEs (at firm level) that undertake the outward FDI (at country level). Indeed, the extent to which these two sets of data are not better correlated is probably due to measurement error and differences in definition, rather than to theoretical differences.

How can the eclectic paradigm be reconciled with internalization theory based on the logic of this paper? The simplest solution is to abandon the treatment of ownership advantages as a separate category in the eclectic paradigm. Instead, the firm-specific components of $\mathrm{O}$ advantages should be incorporated with I advantages, and the country-level $\mathrm{O}$ advantages would be better treated as L advantages. 